\title{
Systematic review on screening the role of chemosensitizer or synergistic drug and doxorubicin as dual drug loaded nanoparticle in overcoming multidrug resistant breast cancer
}

\author{
MD Imad Uddin** and B Veeresh** \\ Department of Pharmacology, Pulla Reddy Institute of Pharmacy, Hyderabad-502313, Telangana State, India \\ *Department of Pharmacy, University College of Technology, Osmania University, Hyderabad-500007, Telangana State, India \\ **Department of Pharmacology, G Pulla Reddy College of Pharmacy, Hyderabad-500028, Telangana State, India
}

\section{Article Info}

Article history

Received 10 September 2020

Revised 28 October 2020

Accepted 30 October 2020

Published online 30 December 2020

Keywords

Doxorubicin

Dual drug loaded nanoparticles

Multidrug resistant

Breast cancer

Chemosensitizer drug

\begin{abstract}
Doxorubicin (DOX) is a widely used anticancer drug. Outspread and prolonged usage results in the development of multidrug resistance (MDR). Marry of a chemosensitizer/synergistic drug (CZ/SD) and DOX with a suitable drug delivery platform helped to overcome this problem. In this context, this study is framed to screen the role of chemosensitizer/synergistic drug and DOX as dual drug-loaded nanoparticles (NPs) in overcoming MDR breast cancer. To conduct a literature search authors used the following mesh terms: 'doxorubicin' and 'breast neoplasms' and 'nanoparticles' and 'drug resistance, multiple' and nonmesh terms such as 'dual drug' or 'codelivery' or 'coloaded' or 'coencapsulated' in different databases such as PubMed, google scholar, Science direct and Springer. These databases explored titles and abstracts of original research articles from inception to Jul 2020. This search identified a total of 44 papers. Three duplicate records are removed from these 44 papers. The remaining 41 records were screened by following their titles and abstracts. From 41 records, 14 removed as they were not fulfilling the eligibility criteria of the present study design. After removing sixteen articles (not satisfy inclusion criteria), finally eleven articles were included in this systematic review. This systematic review summarizes the enhanced chemotherapeutic effect of DOX in both in vitro and in vivo MDR cancer models. This improved efficacy of DOX was due to the simultaneous codelivery of DOX and CZ/SD by using a suitable drug delivery platform. In a word, this review emphasizes to move onward to conduct a meta-analysis of similar reported studies.
\end{abstract}

\section{Introduction}

DOX is a well known anthracycline type of chemotherapeutic drug used for the treatment of many types of cancers like lymphoma, sarcoma, leukemia, breast, and lungs (Chatterjee et al., 2010). Suitable therapeutic effect and low cost make it a first-line treatment option for breast cancers (Kathawala et al., 2015). This hydrophilic drug with a half-life of 24-30 h produces cytotoxic action by different mechanisms, viz., (i) generation of oxygen free radicals, (ii) blocking nucleic acid synthesis, (iii) DNA intercalation, (iv) inhibition of a topoisomerase-II enzyme, and (v) anti-angiogenic effect by inhibiting the formation of vascular endothelial growth factor (Pommier et al., 2010; Lee et al., 2009). However, the use of DOX is associated with side effects like cardiotoxicity,

Corresponding author: Mr. MD Imad Uddin Associate Professor, Department of Pharmacology, Pulla Reddy Institute of Pharmacy, Hyderabad-502313, Telangana State, India E-mail: imadpharma111@gmail.com

Tel.: +91-8374175556

Copyright (c) 2020 Ukaaz Publications. All rights reserved.

Email: ukaaz@yahoo.com; Website: www.ukaazpublications.com myelosuppression, low tumor penetration, minimum distribution in solid tumors, and hand-foot syndrome (Tredan et al., 2007).

A salient point to focus on DOX chemotherapy failure is the development of MDR in cancer cells. Four mechanisms which cause MDR are: (i) escaping apoptosis, (ii) increased glutathione conjugation of drugs, (iii) increased repair of damaged DNA, (iv) increased expression of plasma membrane-bound ATP dependent drug efflux pumps, viz., P-glycoprotein (P-gp), MDR associated protein-1 (MRP-1) and breast cancer resistance protein (BCRP) (Mohamed and Skeel, 2007). Over expression of ATP-dependent efflux pumps plays a vital role in the development of DOX related MDR. All three transporters are actively involved in the efflux of passively diffused DOX from cancer cells (Figure 4: Mechanism III) (Lugo and Sharom, 2005). As a first step to overcome this negative aspect, chemosensitizers are advised along with DOX. Verapamil (P-gp inhibitor) and DOX combination approved for clinical trials but showed severe toxicity in phase-III and not scheduled for clinical usage (Belpomme et al., 2000). Valspodar is another P-gp inhibitor, but the use of it was in question due to the development of secondary 
toxicities (Coley, 2010). Different pharmacokinetic profiles and diversified in vivo distribution of co-administered drugs were the focal cause for the failure of combination chemotherapy (Lee and Nan, 2012).

It is imperative to specify that selecting two drugs without modifying their pharmacokinetic profile is not enough to overcome MDR. Thus, an attempt to overcome MDR drugs is delivered by NPs. Targeted drug delivery, longer half-life, enhanced permeability and retention effect, and decreased toxicity are a few noted advantages of this drug delivery system (Yan et al., 2016). However, sequential delivery of drugs, viz., chemosensitizer/ synergistic drug-loaded NPs followed by chemotherapeutic loaded NPs have shown lesser cytotoxic effects than NPs coloaded with both drugs stated above and simultaneously delivered to a tumor (Motevalli et al., 2019). Therefore, research is focused on coencapsulation of DOX and a chemosensitizer or a synergistic drug by using a suitable polymer as a carrier system. Curcumin (CUR), metformin (MET), resveratrol (RES), and elacridar (ELA) are the few P-gp inhibitors investigated by achieving their co-delivery with DOX. These entire dual drug-loaded NPs showed significant anticancer activities than their uncapsulated form or individual encapsulated form. mitomycin-C (MMC), disulfiram (DSF), and docosahexaenoic acid (DHA) are the few synergistic drugs codelivered with DOX and reported improved cytotoxicity of cancer cells with fewer toxic effects. By keeping this, the present study designed to Screen the role of CZ/SD and DOX as dual drug loaded NPs in overcoming MDR breast cancer. This systematic review is the first of its style, where we are emphasizing the importance of CZ/SD loaded along with DOX.

\section{Materials and Methods}

\subsection{Study design and data reporting}

In Jul 2020, an extensive literature search conducted by using the following mesh terms: 'doxorubicin' and 'breast neoplasms' and 'nanoparticles' and 'drug resistance, multiple' and non-meshterm such as 'dual drug' or 'codelivery' or 'coloaded' or 'coencapsulated' in different databases such as PubMed, google scholar, Science direct and Springer. All these databases explored titles and abstracts for original research articles in the English language from inception to Jul 2020. The following does not cover during the search process books, chapters, reviews, patents, protocols, and commentaries. Total identified records screened to exclude duplicate articles and to check their eligibility. Eligibility criterions followed were: (i) original research work, (ii) dual drugloaded NPs (among two drugs, one should be DOX), and (iii) against MDR breast cancer. Non-breast cancer studies and review articles not using NPs as a mode of drug delivery removed as they are not eligible. Inclusion criteria followed for this study are: (i) loaded drugs should be unmodified, (ii) unmodified NPs, (iii) only chemotherapy as a mode of treatment. Papers fulfilled all criteria included in the study. Data processed is depicted in the PRISMA statement (Figure 1).

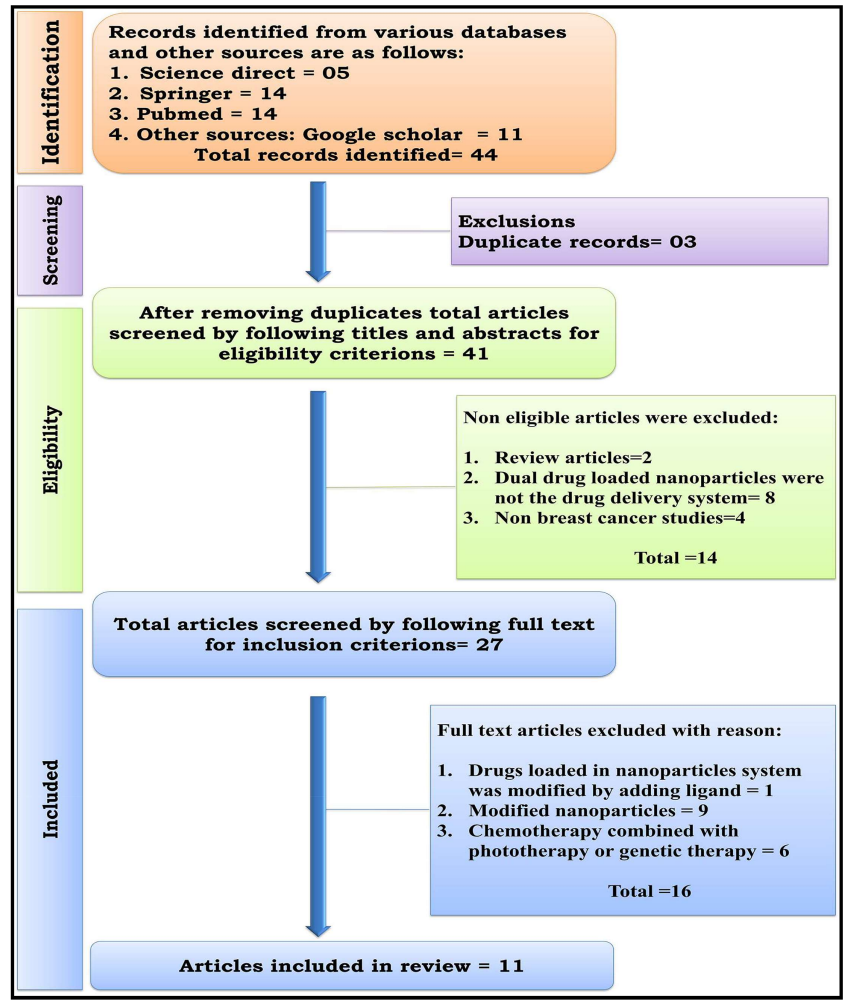

Figure 1: Prisma statement summarizing identification, screening, eligibility, exclusion and inclusion aspects of current study.

\section{Results}

3.1 Search results summary

Exploration of these databases produced 44 articles. Three articles are excluded from the total as they were duplicates. The remaining 41 were screened by following their titles and abstracts. From 41, $14(2=$ review articles; $8=$ dual drug-loaded NPs was not the drug delivery system; and $4=$ non-breast cancer studies) removed as they were not fulfilling the eligibility criteria of the present study design. Leftover 27 records were further screened by following their full text. More 16 articles $(1=\mathrm{Y} 1$ drug loaded in NPs was modified by adding ligands; $9=$ NPs are modified by making them $\mathrm{pH}$-sensitive or magnetic sensitive or conjugating polymer with legumain or folic acid or biotin, and $6=$ chemotherapy combined with phototherapy or genetic therapy) eliminated as they were not satisfying inclusion criteria. Finally, eleven articles satisfied all inclusion criteria, so included for the systematic review. Table 1 summarizes the preparation, characterization parameters of NPs, and Table 2 Summarizes antibreast cancer studies of these NPs.

\subsection{DOX and CUR}

Among 11 full text included studies, 2 of them used CUR as a reversal drug along with DOX. Motevalli et al. (2019) successfully synthesized and characterized DOX-CUR-Albumin NPs (DC-ANPs); DOXAlbumin NPs (D-ANPs); CUR-Albumin NPs (C-ANPs) (Figure 2: Scheme 1). The release of drugs from NPs followed first-order kinetics in an acidic environment, but the release of CUR is slower than DOX because it has strong bonding with the polymer. The authors used both simultaneous and sequential (C-ANPs followed by D-ANPs) treatment patterns against MCF-7 cells. Sequential exposure resulted 
in lysosomotropism of CUR, which resulted in a lesser degree of cytotoxicity. But simultaneous exposure resulted in greater cellular accumulation of both drug molecules, followed by a higher degree of cytotoxicity. This process was supported by higher lysosomal $\mathrm{pH}$ in these cells. Finally, the overwhelming benefits of codelivery indicated by decreased expression of P-gp in these treated cells. Duan et al. (2012) synthesized DOX-CUR-chitosan/poly (butyl cyanoacrylate (PBCA) NPs (DC-PBCANPs) (Figure 2: Scheme 2). To obtain well-formulated NPs, CUR was added $10 \mathrm{~min}$ before the polymerization reaction to avoid precipitation of drug and aggregation of the polymer. Increase in the concentration of chitosan $(0.055 \%$ to $0.2 \%)$ and $\alpha-\mathrm{BCA}(0.5 \%$ to $2.0 \%)$ improved characteristic features of NPs. An increase in CUR concentration slowed down DOX polymerization, but an increase in DOX concentration did not affect CUR polymerization. A broad endothermic peak at $163.6^{\circ} \mathrm{C}$ with a $\Delta \mathrm{H}$ value of $227.5 \mathrm{j} / \mathrm{g}$ indicates the physicochemical stability of formulated NPs. These findings suggest the successful encapsulation of both drugs and the complete polymerization of $\alpha$-BCA. DC-PBCANPs showed $96.94 \%$ of cytotoxicity against MCF-7/ADR cells. Further, the sensitivity of resistant cells to NPs confirmed after a decreased expression of P-gp in them.

\subsection{DOX and MMC}

A total of 4 out of 11 full-text studies used MMC as a reversal drug. Figure 2: Scheme 3 explains the synthesis of DOX and MMC coloaded polymer lipid hybrid NPs (DM-PLNPs); Zhang et al. (2016), was successful in synthesizing DM-PLNPs and screening their anticancer activity in orthotopic breast tumor mice. These NPs showed distribution throughout the body with higher accumulation in tumor sites for at least $24 \mathrm{~h}$ and minor in the heart and other organs. Both loaded drugs followed a long elimination phase of about $24 \mathrm{~h}$. It is worth noting that DOXOL, a metabolite of DOX showed a gradual increase at the tumor site because of its sustained release pattern from NPs. Increased caspase-3 level designates improved bioavailability of DOX.

As a safety indictor, DOX and DOXOL were least accumulated in heart and showed minimal cardiac toxicity validated by untraceable levels of cTn1. No significant change in body weight, minimal histopathological distortions in the heart, liver, and kidney endorse the safety profile of DOX in DM-PLNPs. Prasad et al. (2013) evaluated the antitumor efficacy of DM-PLNPs in female nu/nu mice bearing solid breast tumors of MDA-MB 435/LCC6/WT and MDA-MB 435/LCC6/MDR cancer cells. DM-PLNPs significantly delayed tumor growth, increased median survival time, no significant loss of body weight, and non-significant change in toxicity related blood enzymes, viz., LDH, ALT, and CK. More specifically, DMPLNPs showed a decrease in vessel number and microvessel density. Prasad et al. (2012) successfully synthesized and characterized spherical shaped DM-PLNPs. These NPs showed a significantly higher degree of cellular trafficking near to perinuclear region and a higher degree of cytotoxicity in MCF-7 WT, MCF-7 VP (overexpressed MRP1+), and MCF-7 MX (overexpressed BCRP+). Shuhendler et al. (2010), synthesized polymer lipid hybrid NPs coloaded with DOX and MMC (DM-PLNPs) with a particle size of $150 \mathrm{~nm}$ on average. From these DM-PLNPs, both drugs followed a biphasic release pattern, the first phase was for $0-5 \mathrm{~h}$ characterized by a burst release of drugs, and the second phase was after $10 \mathrm{~h}$ characterized by sustained release of drugs. The presence of $\mathrm{Ca}^{2+}$ ions increased the release pattern of drugs. These NPs at 20-30 fold lower dose levels, as compared to single drug-loaded NPs or unloaded individual drugs or an unloaded mixture of drugs, showed a higher degree of cytotoxicity in both MDA435/LCC6/WT and MDA435/ LCC6/MDR1 cell lines. Shuhendler et al. (2010) very beautifully described the cellular uptake mechanism of NPs by fluorescence microscopy technique. In both cell lines, these NPs showed endocytotic vesicle-mediated uptake in cells and accumulated near to the perinuclear region of the cytoplasm. In addition, to mark out the cytotoxic mechanism, levels of phospho-dH2AX and activated caspase-3, measured by immunocytochemistry assay. On treatment with DM-PLNPs, signals for phospho-dH2AX (an indicator of DNA double-strand break) were more intense than activated caspase-3 (an indicator of apoptosis). These signals indicate that cytotoxicity was due to DM-PLNPs and was not due to apoptosis.

\subsection{DOX and MET}

Shafiei-irannejad et al. (2018) synthesized a synergistic combination of DOX and MET in poly (lactide-co-glycolide) (PLGA) and D- $\alpha$ tocopheryl polyethylene glycol 1000 succinate (TPGS) polymers (DM-PTNPs) (Figure 2: Scheme 4). Characterization results explain the following: (i) successful coloaded synthesis, (ii) simultaneous release of drugs, and (iii) better cellular uptake of DOX. DM-PTNPs showed a higher degree of cytotoxicity against MCF-7/ DOX cells than all other drug formulations. Further efficacy of DMPTNPs is showed by intense annexin-V-FITC green and PI red fluorescence indicating apoptosis in MCF-7/DOX cells. Higher mean fluorescence intensity due to the accumulation of Rho 123 and decreased cellular ATP content substantiate the effectiveness of NPs.

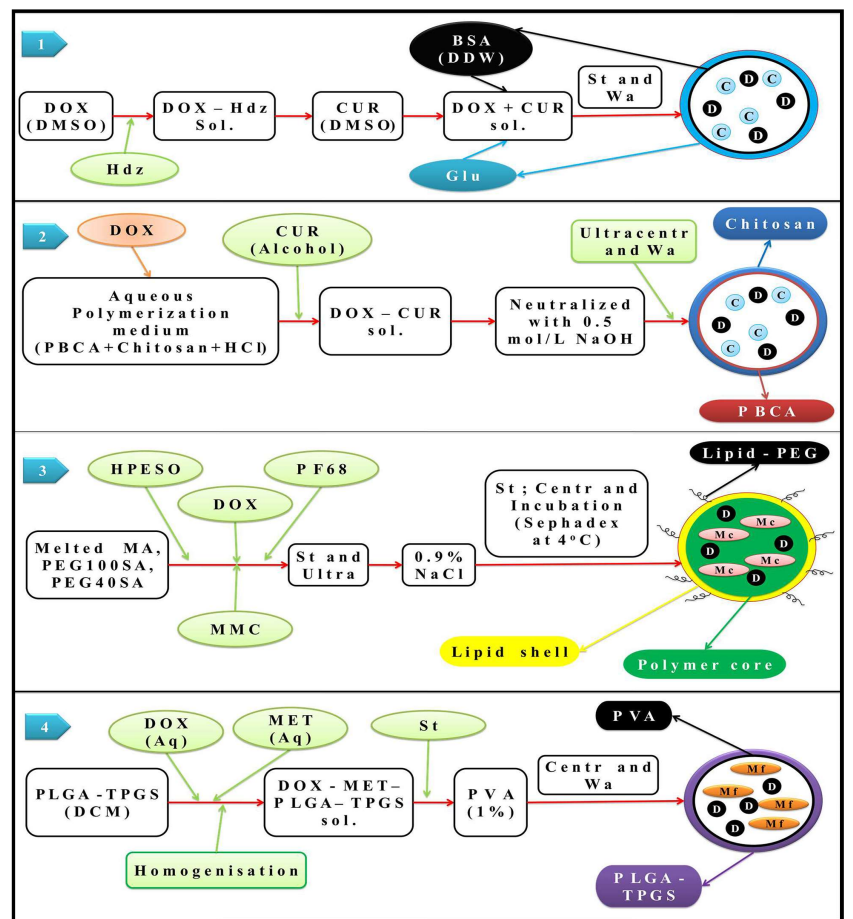

Figure 2: Scheme-1: Synthesis of DC-ANPs by using BSA; Scheme-2: Synthesis of DC-ANPs by using PBCA-Chitosan; Scheme-3: Synthesis of DM-PLNPs; Scheme-4: Synthesis of DMPTNPs; Hdz: Hydrazine; Glu: Glutaraldehyde; MA: Myristic acid; DCM: dichloromethane; PVA: Poly vinyl alcohol. Aq: Aqueous; St: Stirring; Wa: Washing with double distilled water for 3 times; Ultra: Ultrasonication; Centr: Centrifugation; Ultracentr: Ultracentrifugation; 


\subsection{DOX and DSF}

Tao et al. (2018) used amphiphilic poly ( $\varepsilon$-caprolactone) -b- poly (L-glutamic acid) -g- methoxy poly (ethylene glycol) copolymer to coencapsulate DOX and DSF (DD-PPMNPs) (Figure 3: Scheme 1). These DD-PPMNPs reorganize into core-shell-corona structured NPs, in which DOX was loaded by electrostatic interaction and DSF by hydrophobic interaction. Decreased serum protein absorption and improved colloidal stability, sustained release profile, accelerated release in the acidic environment of lysosomes of tumor cells, improved endocytosis mediated vesicular uptake in cells with predominant accumulation in the nuclear region are the few important characteristics of DD-PPMNPs reported in this study. DD-PPMNPs showed synergistic anticancer activity (combination index $=0.12$ ) against MCF-7 and MDA-MB-231 cells. In addition to monolayer model efficacy, DD-PPMNPs also showed efficacy against MCF-7 spheroids by decreasing their size to $44 \%$. Furthermore, DD-PPMNPs showed higher in vivo anticancer efficacy in 4T1 tumor-bearing mice than free drugs and free drug combination, represented by increased tumor accumulation, decreased tumor growth, higher tumor-inhibiting rate, and reduced systemic toxicity.

\subsection{DOX and RES}

Zhao et al. (2016) used poly (lactic-co-glycolic acid) and CHOhyd-PEG-AA polymers to load chemo drug DOX and a reversal drug RES (DR-PCNPs) (Figure 3: Scheme 2). Successfully characterized DR-PCNPs showed higher nuclear accumulation indicated by DOX red and RES green fluorescence in the nuclear region. Because of this, higher degree of cytotoxicity and caspase-3 activity was observed in MDA-MB-231/ADR cells and MCF-7/ ADR cells. To make it clear, the authors screened the cell cycle arresting stage, both types of cancer cells showed reduced expression of cyclins, viz., A1 and D1 and cyclin-dependent kinases, viz., CDK2 and CDK4 indicating G1 phase arrest. Efficacy of DRPCNPs validated by decreased expression of apoptosis-related proteins, viz., NF-kB and BCL-2, and drug resistance-related proteins, viz., P-gp, MRP-1 and BCRP. After the successful screening of in vitro parameters, the authors step forward to evaluate in vivo antitumor activity in tumor-bearing BALB/c nude mice. In this, with comparison to free drugs and free drug combination DR-PCNPs showed higher anticancer activity indicated by decreased tumor growth, no significant change in body weight, increased expression of Bax and caspase-3, reduced expression of NF-kB, BCL-2, P-gp, MRP-1 and BCRP, increased and extended localization in tumor tissues and decreased accumulation in other parts specifically in heart.

\subsection{DOX and DHA}

Mussi et al. (2014) coencapsulated DOX and DHA in a lipid carrier (DD-LNPs) by using a hot homogenization technique (Figure 3: Scheme 3). The release of DOX from DD-LNPs is biphasic. Release of drugs is $5 \%$ in the initial $30 \mathrm{~min}$ and up to $30 \%$ by the end of $4 \mathrm{~h}$. This formulation is suitable for intravenous use as there is no change in size, PDI, and zeta potential of DD-LNPs after incubating with a serum. DD-LNPs showed a higher degree of cytotoxicity in MCF-7 or MCF-7/Adr cells due to increased cellular uptake. Moreover, these DD-LNPs on incubation with spheroids showed a higher degree of penetration of DOX in spheroids and destruction of them after $24 \mathrm{~h}$.

\subsection{DOX and ELA}

Wong et al. (2006) used polymer lipid hybrid to load chemotherapeutic agent DOX and chemosensitizer ELA-reversal agent (DG-PLNPs) (Figure 3: Scheme 4). These spherical shaped NPs showed significant acute and long term cytotoxicity in MDA435/LCC6/MDR1 cells measured by trypan blue exclusion and clonogenic assays. This higher degree of cytotoxicity was well consistent with increased localization in the nuclear region of these cancer cells.

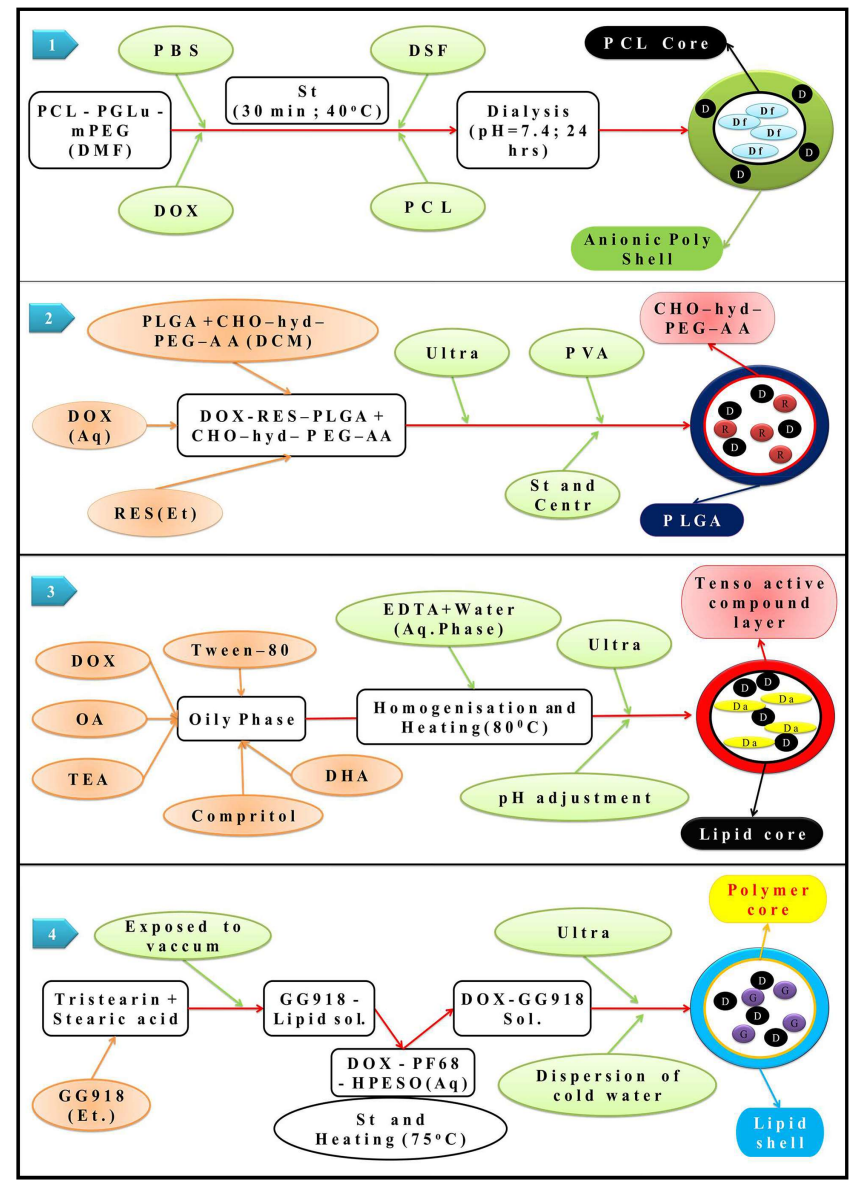

Figure 3: Scheme-1: Synthesis of DD-PPMNPs; Scheme-2: Synthesis of DR-PCNPs; Scheme-3: Synthesis of DD-LNPs; Scheme-4: Synthesis of DG-PLNPs. PVA: Poly vinyl alcohol; PBS: Phosphate buffer saline $\mathrm{pH}=7.4$; DMF: Dimethyl formamide; Aq: Aqueous; Et: Ethanol; OA: Oleic acid; TEA: Tri ethanol amine; St: Stirring; Ultra: Ultrasonication; Centr: Centrifugation. 
Table 1: Summary of preparation and characterization of NPs in different included studies of systematic review

\begin{tabular}{|c|c|c|c|c|c|c|c|c|}
\hline \multirow[t]{2}{*}{ Author (year) } & \multirow[t]{2}{*}{ CZ/SD } & \multicolumn{2}{|c|}{ Polymer and method used for NP preparation } & \multicolumn{5}{|c|}{ Characterization summary of NPs } \\
\hline & & Polymer/lipid & Method & LE (\%) & EE $(\%)$ & PS (n m) & $\mathrm{ZP}(\mathrm{mV})$ & PDI \\
\hline $\begin{array}{l}\text { Motevalli et al. } \\
(2019)\end{array}$ & CUR & BSA & $\begin{array}{l}\text { Emulsion-solvent } \\
\text { evaporation }\end{array}$ & $\begin{array}{l}\text { DOX: } 13.27 \\
\text { CUR: } 9.3\end{array}$ & $\begin{array}{l}\text { DOX: } 86.69 \\
\text { CUR: } 95.46\end{array}$ & 31.4 & -11.6 & 0.193 \\
\hline $\begin{array}{l}\text { Duan et al. } \\
(2012)\end{array}$ & CUR & PBCA & $\begin{array}{l}\text { Emulsion and } \\
\text { interfacial } \\
\text { polymerization }\end{array}$ & $\begin{array}{l}\text { DOX: } 0.61 \\
\text { CUR: } 1.17\end{array}$ & $\begin{array}{l}\text { DOX: } 49.98 \\
\text { CUR: } 94.52\end{array}$ & 133 & +32.23 & - \\
\hline $\begin{array}{l}\text { Zhang et al. } \\
(2016)\end{array}$ & MMC & $\begin{array}{l}\text { Polymer Lipid Hybrid (Polymer: } \\
\text { HPESO, PF68; Lipids: Myristic } \\
\text { acid, PEG100SA, PEG40SA) }\end{array}$ & $\begin{array}{l}\text { Ultrasonication } \\
\text { with some } \\
\text { modifications }\end{array}$ & - & $\begin{array}{l}\text { DOX: } 92 \\
\text { MMC: } 50.6\end{array}$ & 146 & -22.7 & 0.37 \\
\hline $\begin{array}{l}\text { Prasad et al. } \\
(2013)\end{array}$ & MMC & $\begin{array}{l}\text { Polymer Lipid Hybrid (Polymer: } \\
\text { HPESO, PF68; Lipids: Myristic } \\
\text { acid, PEG100SA, PEG40SA) }\end{array}$ & $\begin{array}{l}\text { Ultrasonication } \\
\text { with some } \\
\text { modifications }\end{array}$ & $\begin{array}{l}\text { DOX: } 9.2 \\
\text { MMC: } 3.0\end{array}$ & $\begin{array}{l}\text { DOX: } 92.5 \\
\text { MMC: } 37.8\end{array}$ & 162 & -18.7 & 0.38 \\
\hline $\begin{array}{l}\text { Prasad et al. } \\
(2012)\end{array}$ & MMC & $\begin{array}{l}\text { Polymer Lipid Hybrid (Polymer: } \\
\text { HPESO, PF68; Lipids: Myristic } \\
\text { acid, PEG100SA, PEG40SA) }\end{array}$ & $\begin{array}{l}\text { Ultrasonication } \\
\text { with some } \\
\text { modifications }\end{array}$ & $\begin{array}{l}\text { DOX: } 9.2 \\
\text { MMC: } 3.0\end{array}$ & $\begin{array}{l}\text { DOX: } 92.5 \\
\text { MMC: } 37.8\end{array}$ & 162 & -18.7 & 0.38 \\
\hline $\begin{array}{l}\text { Shuhendler et al. } \\
(2010)\end{array}$ & MMC & $\begin{array}{l}\text { Polymer Lipid Hybrid (Polymer: } \\
\text { HPESO, PF68; Lipids: Myristic } \\
\text { acid, PEG100SA, PEG40SA) }\end{array}$ & $\begin{array}{l}\text { Ultrasonication } \\
\text { with some } \\
\text { modifications }\end{array}$ & $\begin{array}{l}\text { DOX: } 9.32 \\
\text { MMC: } 2.89\end{array}$ & $\begin{array}{l}\text { DOX: } 93.2 \\
\text { MMC: } 36.2\end{array}$ & 147 & -19.2 & - \\
\hline $\begin{array}{l}\text { Shafiei-irannejad } \\
\text { et al. (2018) }\end{array}$ & MET & PLGA + TPGS & Double emulsion & $\begin{array}{l}\text { DOX: } 4.22 \\
\text { Met: } 3.52\end{array}$ & $\begin{array}{l}\text { DOX: } 42.26 \\
\text { Met: } 7.04\end{array}$ & 32.4 & -3.5 & 0.5 \\
\hline $\begin{array}{l}\text { Tao et al. } \\
(2018)\end{array}$ & DSF & $\begin{array}{l}\text { Poly (E-caprolactone) -b- Poly } \\
\text { (L-glutamic acid) -g- Methoxy } \\
\text { poly (ethylene glycol) (PCL- } \\
\text { PGLu-mPEG) }\end{array}$ & Dialysis method & $\begin{array}{l}\text { DOX: } 4.78 \\
\text { DSF: } 4.90\end{array}$ & $\begin{array}{l}\text { DOX: } 95.60 \\
\text { DSF: } 98.00\end{array}$ & 121.4 & - & 0.145 \\
\hline $\begin{array}{l}\text { Zhao et al. } \\
(2016)\end{array}$ & RES & PLGA and CHO-hyd-PEG-AA & $\begin{array}{l}\text { Emulsion-solvent } \\
\text { evaporation }\end{array}$ & $\begin{array}{l}\text { DOX: } 4.6 \\
\text { RES: } 15.5\end{array}$ & - & 170 & -15.8 & 0.14 \\
\hline $\begin{array}{l}\text { Mussi et al. } \\
(2014)\end{array}$ & DHA & Lipid (oleic acid) & $\begin{array}{l}\text { Hot melting } \\
\text { homogenization } \\
\text { using } \\
\text { emulsification- } \\
\text { ultrasound }\end{array}$ & $\begin{array}{l}\text { DOX: } 31 \\
\text { DSA: } 0.4 \%\end{array}$ & $\begin{array}{l}\text { DOX: } 99 \\
\text { DSA: } 0.4 \%\end{array}$ & 86 & -36 & 0.13 \\
\hline $\begin{array}{l}\text { Wong et al. } \\
(2006)\end{array}$ & $\begin{array}{l}\text { GG918 } \\
\text { (ELA) }\end{array}$ & $\begin{array}{l}\text { Polymer Lipid Hybrid (Polymer: } \\
\text { HPESO, PF68; Lipids: Stearic acid) }\end{array}$ & $\begin{array}{l}\text { Ultrasonication } \\
\text { with some } \\
\text { modifications }\end{array}$ & $\begin{array}{l}\text { DOX: } 3.81 \\
\text { ELA: } 0.209\end{array}$ & $\begin{array}{l}\text { DOX: } 76.1 \\
\text { ELA : } 83.5\end{array}$ & 272 & -19.4 & - \\
\hline
\end{tabular}

Table 1: Summary of preparation and characterization parameters of NPs synthesized in selected full text articles. DOX is the drug loaded along with CZ/SD. All characterization parameters are measured by different procedures by different authors. Unless specified shape of NPs mentioned was determined by TEM. Studies in which many formulation were used, results of the best formulation is mentioned. HPESO=Hydrolyzed polymer of epoxidized soybean oil; PF68=Pluronic F-68; PEG100SA=poly(ethylene glycol)-100stearate; PEG40SA= poly(ethylene glycol)-40-stearate; LE=Loading efficiency; EE=Encapsulation efficiency; PS=Particle size; ZP=Zeta potential; PDI= Poly dispersity index; TEM=Transmission electron microscopy. 
Table 2: Summary of anti breast cancer activity conducted in included full text studies of systematic review

\begin{tabular}{|c|c|c|}
\hline Author (year) & Parameters screened for evaluation of anticancer activity & End results of anticancer activity \\
\hline $\begin{array}{l}\text { Motevalli et al. } \\
(2019)\end{array}$ & $\begin{array}{l}\text { In vitro study: (In following parameters MCF-7 cells are } \\
\text { exposed to DC-ANPs) } \\
\text { 1. MCF-7 cells viability was measured by MTT assay. } \\
\text { 2. Fluorescence activated cell sorting FACS measurements } \\
\text { by flow cytometry. } \\
\text { 3. Co-localization of drugs within the lysosomes by } \\
\text { confocal laser scanning microscope } \\
\text { 4. Measurements of lysosomal pH by Attune acoustic focusing } \\
\text { cytometer } \\
\text { 5. Expression of P-gp was assessed by Western blotting. }\end{array}$ & $\begin{array}{l}\text { In MCF-7 cells treated with DC-ANPs } \\
\text { 1. \% Cell viability was decreased. } \\
\text { 2. DOX concentration was highest in MCF-7 cells. } \\
\text { 3. Diffused signals arising from both drugs localized in } \\
\text { lysosomes. } \\
\text { 4. Increased lysosomal pH by DOX and causing rupture of } \\
\text { lysosomes. } \\
\text { 5. Decreased expression of P-gp }\end{array}$ \\
\hline $\begin{array}{l}\text { Duan et al. } \\
(2012)\end{array}$ & $\begin{array}{l}\text { In vitro study: (In following parameters MCF-7/ADR cells } \\
\text { are exposed to DC-PBCANPs) } \\
\text { 1. \% inhibition of cell growth was measured by MTT assay. } \\
\text { 2. Determination of MDR proteins in MCF-7/ADR cells was } \\
\text { assessed by Western blotting. } \\
\end{array}$ & $\begin{array}{l}\text { In MCF-7/ADR cells treated with DC-PBCANPs } \\
1 . \% \text { inhibition was found to be } 96.94 \\
\text { 2. Expression of P-gp and ABCG2 was declined. }\end{array}$ \\
\hline $\begin{array}{l}\text { Zhang et al. } \\
(2016)\end{array}$ & $\begin{array}{l}\text { In vivo study: (female mice exposed to EMT6/WT murine } \\
\text { breast cancer cells and treated with DM-PLNPs or ICG-DM- } \\
\text { PLNPS) } \\
\text { 1. Bio-distribution of ICG-DM-PLNPs detected in whole body } \\
\text { of mice by Xenogen IVIS in vivo imaging system and in ex vivo } \\
\text { organs by fluorescence microscopy. } \\
\text { 2. Pharmacokinetics and bio-distribution measured by HPLC } \\
\text { or LC-MS/MS. } \\
\text { 3. Acute toxicity study: parameters measured are body weight; } \\
\text { plasma cTnI levels; histopathological study of heart, } \\
\text { kidney and liver. } \\
\text { 4. Apoptosis measured by immuno histochemical staining } \\
\text { technique }\end{array}$ & $\begin{array}{l}\text { In female mice treated with DM-PLNPS or ICG-DM-PLNPs } \\
\text { 1. Intense fluorescence in breast tumor areas indicating } \\
\text { accumulation of ICG-DM-PLNPs. Moreover ex-vivo images } \\
\text { showed accumulation in many organs including tumor areas } \\
\text { except heart. } \\
\text { 2. Delivery of drugs decreased bi-exponentially over } 24 \mathrm{~h} \\
\text { with long elimination } \mathrm{t} 1 / 2 \text {. DOXOL levels increased gradually } \\
\text { at tumor sites but not in heart indicating local } \\
\text { bioavailability. } \\
\text { 3. No weight loss; undetectable cTnI levels; minimal } \\
\text { distortion of histoarchitecture in heart, kidney and liver. } \\
\text { 4. Increased expression of caspase-3 indicating apoptosis. }\end{array}$ \\
\hline $\begin{array}{l}\text { Prasad et al. } \\
(2013)\end{array}$ & $\begin{array}{l}\text { In vivo study: (female mice exposed to either MDA-MB } 435 / \\
\text { LCC6/WT or MDA-MB } 435 / \mathrm{LCC} 6 / \mathrm{MDR} 1 \text { cells and treated with } \\
\text { DM-PLNPs) } \\
\text { 1. Determination of DM-PLNPs dose for study. } \\
\text { 2. Anti-tumor efficacy in sensitive and MDR tumor models } \\
\text { by screening median survival time and \% increase in life } \\
\text { span. } \\
\text { 3. Screening safety and normal tissue toxicity } \\
\text { 4. Screening expression of CD31 by immunohistochemical } \\
\text { staining technique and microvessel density of tumors. }\end{array}$ & $\begin{array}{l}\text { In both sensitive and resistant female mice treated with } \\
\text { DM-PLNPs } \\
\text { 1. Dose selected for study was } 25 \mathrm{mg} / \mathrm{m}^{2} \text { as } 50 \mathrm{mg} / \mathrm{m}^{2} \text { showed } \\
\text { systemic toxicity. } \\
\text { 2. Antitumor efficacy was indicated by delay in average time } \\
\text { for tumor growth; delay in \% of tumor growth; increased } \\
\text { median survival time and overall life span in both tumor } \\
\text { models. } \\
\text { 3. No systemic toxicity was observed indicated by no change } \\
\text { in weight of animals over complete study duration and no } \\
\text { significant change in the levels of enzymes, viz, LDH, ALT } \\
\text { and CK. } \\
\text { 4. Anti-angiogenic effect indicated by decreased expression } \\
\text { of CD31 and significant decrease in vessel number and } \\
\text { microvessel density in tumor tissues. }\end{array}$ \\
\hline $\begin{array}{l}\text { Prasad } e t \\
(2012)\end{array}$ & $\begin{array}{l}\text { In vitro study: (In following parameters MCF7 WT, MCF7 VP } \\
\text { and MCF7 MX cells are exposed to DOX or MMC) } \\
\text { 1. Surviving fraction of cells measured by clonogenic assay. } \\
\text { 2. By employing median effect analysis to clonogenic assay } \\
\text { results: shape of curve, median effect dose, dose reduction } \\
\text { index and combination index were determined }\end{array}$ & $\begin{array}{l}\text { In MCF7 WT, MCF7 VP and MCF7 MX cells treated with DOX or } \\
\text { MMC } \\
\text { 1. Surviving fraction was equal for both drugs in MCF7 WT } \\
\text { cells, whereas fraction is more for DOX than MMC in other } \\
\text { two cell lines. } \\
\text { 2. Sigmoid shape curve }(\mathrm{m}>1) \text {; median effect dose, dose } \\
\text { reduction index was more for MCF7 VP and MCF7 MX cells } \\
\text { than MCF7 WT cells, synergistic interaction }(\mathrm{CI}>1)\end{array}$ \\
\hline
\end{tabular}




\begin{tabular}{|c|c|c|}
\hline Author & Irameters screened for evaluation of anticancer activity & End results of anticancer activity \\
\hline & $\begin{array}{l}\text { In following parameters MCF7 WT, MCF7 VP and MCF7 MX cells } \\
\text { are exposed to DM-PLNPS } \\
\text { 1. Surviving fraction and \% kill of cells measured by clonogenic } \\
\text { assay. } \\
\text { 2. Cellular distribution of drugs by fluorescence microscopy. }\end{array}$ & $\begin{array}{l}\text { In MCF7 WT, MCF7 VP and MCF7 MX cells treated with DM- } \\
\text { PLNPs } \\
\text { 1. Surviving fraction was less and \% kill of cells was more } \\
\text { when compared to free drugs. } \\
\text { 2. Intense fluorescence inside and near to nucleus indicates } \\
\text { cellular uptake of drugs. }\end{array}$ \\
\hline $\begin{array}{l}\text { Shuhendler et al. } \\
(2010)\end{array}$ & $\begin{array}{l}\text { In vitro study: (In following parameters MDA-MB } 435 / \mathrm{LCC} 6 / \\
\text { WT or MDA-MB 435/LCC6/MDR1 cells are exposed to DOX or } \\
\text { MMC or both) } \\
\text { 1. Surviving fraction of cells measured by clonogenic assay. } \\
\text { 2. By employing median effect analysis to clonogenic assay } \\
\text { results: Median effect dose, and combination index were } \\
\text { determined } \\
\text { 3. Determining the source of DNA double strand breaks by } \\
\text { using immunohistochemical staining technique. } \\
\text { In following parameters MDA-MB } 435 / \mathrm{LCC} 6 / \text { WT or MDA-MB } 435 / \\
\text { LCC6/MDR1 cells are exposed to DM-PLNPs } \\
\text { 1. Surviving fraction of cells measured by clonogenic assay. } \\
\text { 2. Determination of cellular uptake and intercellular } \\
\text { distribution by fluorescence microscopy. } \\
\text { 3. Determining the source of DNA double strand breaks by } \\
\text { using immunohistochemical staining technique. }\end{array}$ & $\begin{array}{l}\text { In MDA-MB 435/LCC6/WT or MDA-MB 435/LCC6/MDR1 cells } \\
\text { treated with DOX or MMC or both } \\
\text { 1. Surviving fraction was decreased in both cells lines when } \\
\text { exposed to combination therapy than individual drug therapies. } \\
\text { 2. Median effect dose was lesser for combination therapy } \\
\text { than individual drug treatments, synergistic interaction (CI>1) } \\
\text { 3. Source of breaks was exposure to drugs because immediately } \\
\text { after exposure Phospho-dH2AX was stained (indicator of } \\
\text { DNA double strand breaks) with very little caspase-3 staining } \\
\text { (indicator of apoptosis). Moreover staining was intense in } \\
\text { combination therapy. } \\
\text { In MDA-MB } 435 / \mathrm{LCC} 6 / \text { WT or MDA-MB } 435 / \mathrm{LCC} 6 / \mathrm{MDR} 1 \text { cells } \\
\text { treated with DM-PLNPs } \\
\text { 1. Surviving fraction was less when compared to free drugs. } \\
\text { 2. In both cell lines NPs are taken up by membrane bound } \\
\text { vesicles and transported to nucleus. } \\
\text { 3. Source of breaks was exposure to drugs because immediately } \\
\text { after exposure Phospho-dH2AX was stained (indicator of } \\
\text { DNA double strand breaks) with very little caspase-3 staining } \\
\text { (indicator of apoptosis). Moreover staining was intense with } \\
\text { DM-PLNPs when compared to free and combination drugs. }\end{array}$ \\
\hline $\begin{array}{l}\text { Shafiei-irannejad } \\
\text { et al. (2018) }\end{array}$ & $\begin{array}{l}\text { In vitro study: (In following parameters MCF-7/DOX Cells are } \\
\text { exposed to DM-PTNPs) } \\
\text { 1. Cellular uptake of drugs was determined by confocal laser } \\
\text { scanning microscopy. } \\
\text { 2. \% cells viability was measured by MTT assay. } \\
\text { 3. Analysis of apoptosis using flow cytometry. } \\
\text { 4. Intracellular mean fluorescent intensity of rhodamine-123 } \\
\text { was measured by fluorometer. } \\
\text { 5. Intracellular ATP determination }\end{array}$ & $\begin{array}{l}\text { In MCF-7/DOX cells treated with DM-PTNPs } \\
\text { 1. Clear fluorescence indicating uptake of DOX. } \\
\text { 2. \% cell viability was decreased (IC-50=432 } \pm 66.2 \mathrm{ng} / \mathrm{ml} \text { ) } \\
\text { 3. Intense fluorescence indicating apoptosis. } \\
\text { 4. Higher mean fluorescent intensity indicating accumulation } \\
\text { of rhodamine- } 123 \text {. } \\
\text { 5. Decreased intracellular ATP content. }\end{array}$ \\
\hline $\begin{array}{l}\text { Tao } 2018 \text { et al. } \\
(2018)\end{array}$ & $\begin{array}{l}\text { In vitro study: (In following parameters MCF-7 or MDA-MB-231 } \\
\text { cells are exposed to DD-PPMNPs) } \\
\text { 1. Measurement of \% cell viability and combination index by } \\
\text { MTT assay. } \\
\text { 2. Qualitative cellular uptake of DOX in MCF-7 cells was } \\
\text { measured by confocal laser scanning microscopy. } \\
\text { 3. Quantitative uptake of DOX expressed as intracellular } \\
\text { fluorescence intensity in MCF-7 cells measured by flow cytometry. } \\
\text { 4. Morphology and size of MCF-7 spheroids assessed by inverted } \\
\text { microscope. } \\
\text { In vivo study: (female BALB/c mice exposed to } 4 \mathrm{~T} 1 \text { cells and } \\
\text { treated with DD-PPMNPs) } \\
\text { 1. Antitumor activity: Body weight, tumor volume, tumor } \\
\text { weight, tumor inhibition rate. }\end{array}$ & $\begin{array}{l}\text { In vitro study: In MCF-7 or MDA-MB-231 cells treated with DD- } \\
\text { PPMNPS } \\
\text { 1. \% cell viability was decreased and synergistic effect was } \\
\text { produced in both cell lines indicated by } \mathrm{CI}<0.9 \text {. } \\
\text { 2. Intense fluorescence in cells mainly at nucleus indicates } \\
\text { accumulation of DOX. } \\
\text { 3. Intracellular fluorescence intensity is increased indicating } \\
\text { accumulation of DOX. } \\
\text { 4. Spheroids disassembled and decreased in size. } \\
\text { In vivo study: (In female BALB/c } 4 \mathrm{~T} 1 \text { tumor bearing mice } \\
\text { treated with DD-PPMNPs) } \\
\text { 1. Antitumor effect was revealed by no or less change in } \\
\text { weight of animal, decreased tumor volume and tumor } \\
\text { weight, increased tumor inhibiting rate. }\end{array}$ \\
\hline
\end{tabular}




\begin{tabular}{|c|c|c|}
\hline Author (year) & Parameters screened for evaluation of anticancer activity & End results of anticancer activity \\
\hline $\begin{array}{l}\text { Zhao et al. } \\
(2016)\end{array}$ & $\begin{array}{l}\text { In vitro study: (In following parameters MDA-MB-231/ADR } \\
\text { cells and MCF-7/ADR cells are exposed to DR-PCNPs) } \\
\text { 1. \% cells viability was measured by MTT assay. } \\
\text { 2. Caspase } 3 \text { activity } \\
\text { 3. Cellular uptake of drugs was determined by confocal laser } \\
\text { scanning microscopy. } \\
\text { 4. Cell cycle analysis by using flow cytometry. } \\
\text { 5. Drug resistance-related protein and apoptosis-related } \\
\text { protein expression in tumor cells by western blotting. } \\
\text { In vivo study: (female BALB/c nude mice exposed to MDA-MB- } \\
\text { 231/ADR cells and treated with DR-PCNPs) } \\
\text { 1. Weight of mice; tumor growth and volume; level of drug } \\
\text { resistance-related protein and apoptosis-related protein in } \\
\text { tumor tissue. } \\
\text { 2. In vivo drug distribution was measured by Caliper IVIS Lumina } \\
\text { II in vivo image system and Fluorescence microscopy. } \\
\text { 3. Histopathological analysis of tumor tissues and organs. }\end{array}$ & $\begin{array}{l}\text { In vitro: In MDA-MB-231/ADR cells and MCF-7/ADR cells } \\
\text { treated with DR-PCNPs } \\
\text { 1. \% Cell viability was decreased. } \\
\text { 2. Caspase-3 activity was increased } \\
\text { 3. Higher nuclear accumulation of both drugs indicated by } \\
\text { intense red (DOX) and green (RES) fluorescence. } \\
\text { 4. Cells are arrested in G1 phase. } \\
\text { 5. Down regulated the expression of P-gp, MRP-1, BCRP, NF- } \\
\text { kB, BCL-2 and up regulated the expression of Bax } \\
\text { In vivo study: Female BALB/c nude mice are treated with } \\
\text { DR-PCNPS } \\
\text { 1. No loss in weight of mice; tumor growth and volume } \\
\text { decreased; down regulated the expression of P-gp, MRP-1, } \\
\text { BCRP, NF-kB, BCL-2 and up regulated the expression of Bax } \\
\text { and Caspase-3. } \\
\text { 2. Higher amount of drugs were distributed in tumor tissues } \\
\text { when compared to normal and heart tissues. } \\
\text { 3. Histopathological changes were observed in tumor tissues sections. }\end{array}$ \\
\hline $\begin{array}{l}\text { Mussi et al. } \\
(2014)\end{array}$ & $\begin{array}{l}\text { In vitro study: (In following parameters MCF-7 or MCF-7/Adr } \\
\text { cells are exposed to DD-LNPs) } \\
\text { 1. Measurement of \% cell viability. } \\
\text { 2. Cellular drug uptake measured by Fluorescence activated } \\
\text { cell sorting measurements using flow cytometry. } \\
\text { 3. Cytotoxicity (indicated by measurement of \% released } \\
\text { LDH) of spheroids made from MCF-7/ADR cells detected by } \\
\text { CytoTox } 96 \text { Non-Radioactive Cytotoxicity Assay } \\
\text { 4. Penetration of DOX through spheroids (model of avascular } \\
\text { tumor) by confocal microscopy. }\end{array}$ & $\begin{array}{l}\text { In MCF-7 or MCF-7/Adr cells treated with DD-LNPs } \\
\text { 1. \% cell viability was decreased. } \\
\text { 2. DOX uptake is higher in MCF-7/Adr cells than MCF-7 cells. } \\
\text { 3. \% released LDH is increased which denotes increased } \\
\text { cytotoxicity of spheroids. } \\
\text { 4. Intense fluorescence in deepest layers of spheroids } \\
\text { indicating maximum penetration of DOX. }\end{array}$ \\
\hline $\begin{array}{l}\text { Wong et al. } \\
(2006)\end{array}$ & $\begin{array}{l}\text { In vitro study: (In following parameters MDA435/LCC6/MDR1 } \\
\text { cells are exposed to DG-PLNPs) } \\
\text { 1. Acute cytotoxicity by trypan blue exclusion assay. } \\
\text { 2. Uptake of DOX } \\
\text { 3. Long term cytotoxicity by clonogenic assay } \\
\text { 4. Cellular distribution of DOX by fluorescence microscopy. }\end{array}$ & $\begin{array}{l}\text { In MDA435/LCC6/MDR1 cells treated with DG-PLNPS } \\
\text { 1. Higher acute cytotoxicity. } \\
\text { 2. DOX uptake was maximum } \\
\text { 3. Highest long term cytotoxicity. } \\
\text { 4. Intense fluorescence in cytoplasmic and nuclear region } \\
\text { indicates DOX distribution in these regions. }\end{array}$ \\
\hline
\end{tabular}

\section{Discussion}

A range of non-toxic and biocompatible polymers are used in included studies to synthesize dual drug-loaded NPs. Bovine serum albumin (BSA) is renowned with suitable characteristic features, significant to mention is good enhanced permeability and retention effect (Noorani et al., 2015; Wu et al., 2017) and can load both hydrophobic and hydrophilic drugs (Elzoghby et al., 2012). Two glycoproteins, namely; GP-60 and osteonectin, play a vital role in the targeted delivery of albumin NPs to breast cancer cells. GP-60 a glycoprotein expressed on endothelium cells that bind and promote vesicular transcytosis of albumin NPs and osteonectin, a matricellular glycoprotein which is over-expressed on breast cancer cells and binds to albumin and helps in the delivery of drugs (Ding et al., 2018; Lin et al., 2016). To highlight the importance of albumin polymer, it is worth mentioning FDA-approved formulation, Abraxane ${ }^{\circledR}$. It is paclitaxel bounded albumin NPs approved in 2005 for the treatment of breast cancer. It uses the above-said receptors to deliver drug cargo. Poly butyl cyanoacrylate belongs to poly cyanoacrylates class is a stable drug carrier with quick elimination from the body because of low molecular weight of $153.18 \mathrm{~g} \mathrm{~mol}^{-1}$ (Koffie et al., 2011). Thereafter, Duan et al. (2012) published CUR encapsulation resulted in spherical NPs of $130 \mathrm{~nm}$ of average size. Similarly, Zhao et al. (2016) in 2016, used PLGA as a drug delivery system for DOX and RES. The release of drugs from PLGA NPs is by diffusion from water filled pores. This PLGA has many disadvantages, viz., hydrophobicity, rapid removal by the reticulo-endothelial system, and enduring incompatible behavior towards blood cells. A renowned modification is complexing with TPGS manages this problem. In an included study carried out by Shafiei-irannejad et al. (2018). TPGS was complexed with PLGA in the presence of catalyst stannous octate and used to co-deliver DOX and MET. Certain limitations of PLGA, viz., incompatibility, hydrophobicity managed when complexed with TPGS. Besides, complex with TPGS has an added advantage as it also has P-gp inhibiting property. Recently Gaonkar et al. (2017) used the same copolymer to deliver gracinol for cancer treatment emphasizing the applicability of PLGA-TPGS copolymer as a drug 
delivery carrier. Another important amphiphilic copolymer PCLb-PGlu-g-mPEG reorganizes into core-shell corona structured nanocarrier in an aqueous environment. This nanocarrier has three regions, namely; hydrophobic inner core is formed by poly $(\varepsilon-$ caprolactone) that can accommodate hydrophobic drugs, a hydrophilic middle poly (glutamic acid) shell which can accommodate hydrophilic drugs, and hydrophilic outer polyethylene glycol chains which can increase in vivo circulation time. Because of varied advantages, in terms of particle size, stability release kinetics, in vitro and in vivo breast cancer efficacy, this core-shell corona structured NPs are emerging as a promising carrier for drug delivery (Tao et al., 2018).

Apart from polymer NPs lipid-based nanoformulations are also gaining importance. Two lipid-based nanoformulations, viz., solidlipid carriers, and nanostructured lipid carriers are widely used because of their biocompatible nature and easy method of preparation. Among these two, nanostructured lipid carriers have few advantages over solid-lipid-carriers. As an improved version of solid-lipid-carriers, nanostructured lipid carriers have a crystal structure formed from solid and liquid lipids with an improved drug encapsulation property (Muller et al., 2002). DD-LNPs synthesized by Mussi et al. (2014), showed 30\% of the drug was released by burst effect, as controlled drug release is a challenge with nanostructured lipid carriers (Radtke and Muller, 2001). Another disadvantage is the minimum encapsulation of hydrophilic drugs (Serpe et al., 2004). Polymer-lipid hybrid NPs are used to overcome these drawbacks. These are emerging as next-generation drug delivery carriers. Four included studies used polymer lipid hybrid as a drug carrier system. Outer lipid-polyethylene glycol coating that imparts steric stabilization property and improves in vivo circulation time. The inner lipid shell that makes it biocompatible and imparts sustained-release property to encapsulated drugs and central polymeric core where drugs get encapsulated are few advantages of polymer lipid hybrid NPs over liposomes and other polymeric NPs (Hadinoto et al., 2013). These polymer lipid hybrid NPs are not only used to deliver lipophilic cationic compounds like DOX and Verapamil (Wong et al., 2004), but also for the delivery of lipophilic nonionic compounds like DOX and GG918 (Wong et al., 2006). The outer coating is decorated with different entities to make them more useful. Wu et al. (2015) synthesized folate ligand-coated polymer lipid hybrid DOX NPs, Gao et al. (2017) successfully developed arginylglycyl aspartic acid (iRGD) decorated polymer lipid hybrid isoliquiritigenin NPs. Thus, from the above discussion, it is clear to understand the importance of the proper selection of the drug delivery system for overcoming MDR.

It is worth to consider not only the encapsulation of drugs but also their sequence of administration. Motevalli et al. (2019) showed that sequential administration of a chemo-sensitizer C-ANPs and a chemotherapeutic drug D-ANPs is less effective when compared to the simultaneous administration of these drugs. It was clearly described in sequential administration when MCF-7 cells are first exposed to C-ANPs than later on to D-ANPs. CUR released from C-ANPs gets entrapped in lysosomes; a phenomenon called lysosomotropism, and failed to control the expression of P-gp pumps on the surface of breast cancer cells. As a result, as soon as DOX released into the cytosol from D-ANPs, it is readily pumped out by P-gp, an MDR protein. Whereas, in the case of simultaneous administration where both drugs are present in the same NPs- DCANPs. These DC-ANPs undergo transcytosis through the endothelial layer of the blood vessel wall by binding to GP-60, a receptor for albumin to bind. After reaching the interstitial space of the tumor DC-ANPs, enter breast cancer cells by binding to osteonectin, an albumin binding protein expressed on breast cancer cells. When both drugs reach simultaneously, DOX increases lysosomal $\mathrm{pH}$, followed by swelling and release of both drugs into the cytosol of cells. CUR released will inhibit P-gp pump expression and, thus prevents the efflux of DOX. The higher intracellular concentration of DOX will ultimately lead to a cytotoxic effect in a cell representing the synergistic action of both drugs (Figure 4: Mechanism I). Ducreux et al. (2011) reported similar advantages upon using simultaneous over sequential delivery of chemotherapeutic drugs for the treatment of advanced colorectal cancer.

Duan et al. (2012) reported the chemosensitizing and synergistic action on simultaneous delivery of CUR and DOX encapsulated in PBCA coated chitosan, i.e., DC-PBCANPs against MCF-7 and MCF7/ADR cells. These DC-PBCANPs are more efficacious than NPs loaded with either DOX or CUR and was also superior to free drugs or free drug combinations. These NPs escape the bloodstream through leaky vasculature at the site of the tumor. They had chitosan coating on the surface, a positively charged surfactant that binds to the negatively charged plasma membrane. After endocytotic entry into tumor-cell, there is a simultaneous release DOX and CUR from endosomes. The rupture of these endosomes is due to an increase in $\mathrm{pH}$. As reported, DOX increases $\mathrm{pH}$ and causes the rupture of these vesicles. As mentioned above, CUR blocks P-gp pump and prevents the loss of DOX. As a result, both cell lines reported a higher degree of cytotoxicity (Figure 4: Mechanism IV).

Thus CUR is acting as a chemosensitizer along with DOX because it inhibits the P-gp efflux pump. In place of chemosensitizers, a synergistic drug-like docosahexaenoic acid was coencapsulated with DOX in nanostructured lipid carriers (DD-LNPs). This drug delivery system showed a higher degree of cytotoxicity against MCF-7/ADR cells and also against spheroids (in vitro tumor model that mimics in vivo tumors) (Perche and Torchilin, 2012). Docosahexaenoic acid increases oxidative stress and lipid peroxidation in tumor cells and making them more sensitive to DOX (Mussi et al., 2014). Another synergistic drug MMC is also coloaded with DOX in a newly formulated drug carrier system called as polymer lipid hybrid NPs. These NPs are coated with PEG to impart stealth properties, viz., inhibition of NPs aggregation, preventing recognition by opsonins and, thus inhibiting phagocytosis by mononuclear phagocyte system, achieving prolonged circulation time and targeted delivery of drug cargo (Suk et al., 2016). Enhanced permeability and retention effect achieved due to inadequately developed leaky vasculature and damaged lymphatic system of tumors. These DMPLNPs enters the tumor cell by endocytosis. Membrane-bound vesicles formed not only pass the cell membrane but also travel to the perinuclear region and bypassing the efflux protein pumps. DOX released from NPs is either metabolized (small quantity) by aldo-keto reductase into DOXOL, a cardiotoxic metabolite, or moves into the nucleus. MMC adds an alkyl group to DNA and induces breaks in it that causes the synthesis of repair proteins. These repair proteins interact with the topoisomerase-II-alpha-DOX-DNA 
complex and increase the production of phospho-gamma-H2AX an indicator of DNA double-strand breaks that finally induces cytotoxicity. The induction of cytotoxicity was due to DNA doublestrand breaks but not due to apoptosis. This process of cytotoxicity is verified by evaluating the levels of apoptotic indicator caspase-3. The initial formation of phospho-gamma-H2AX and later on of caspase- 3 indicates that cytotoxicity is due to DNA double-strand breaks (Figure 4: Mechanism II) (Prasad et al., 2012; Prasad et al., 2013; Shuhendler et al., 2010; Zhang et al., 2016). In another study, DOX was coencapsulated with ELA (GG918), a Pgp inhibitor in polymer lipid-hybrid delivery system (DG-PLNPs). These NPs have a mechanism similar to DC-PBCANPs. In a word, ELA inhibits the P-gp pump and increases the intracellular accumulation of DOX. This process results in a higher degree of cytotoxicity and improves the therapeutic effect of DOX in MDR breast cancers.

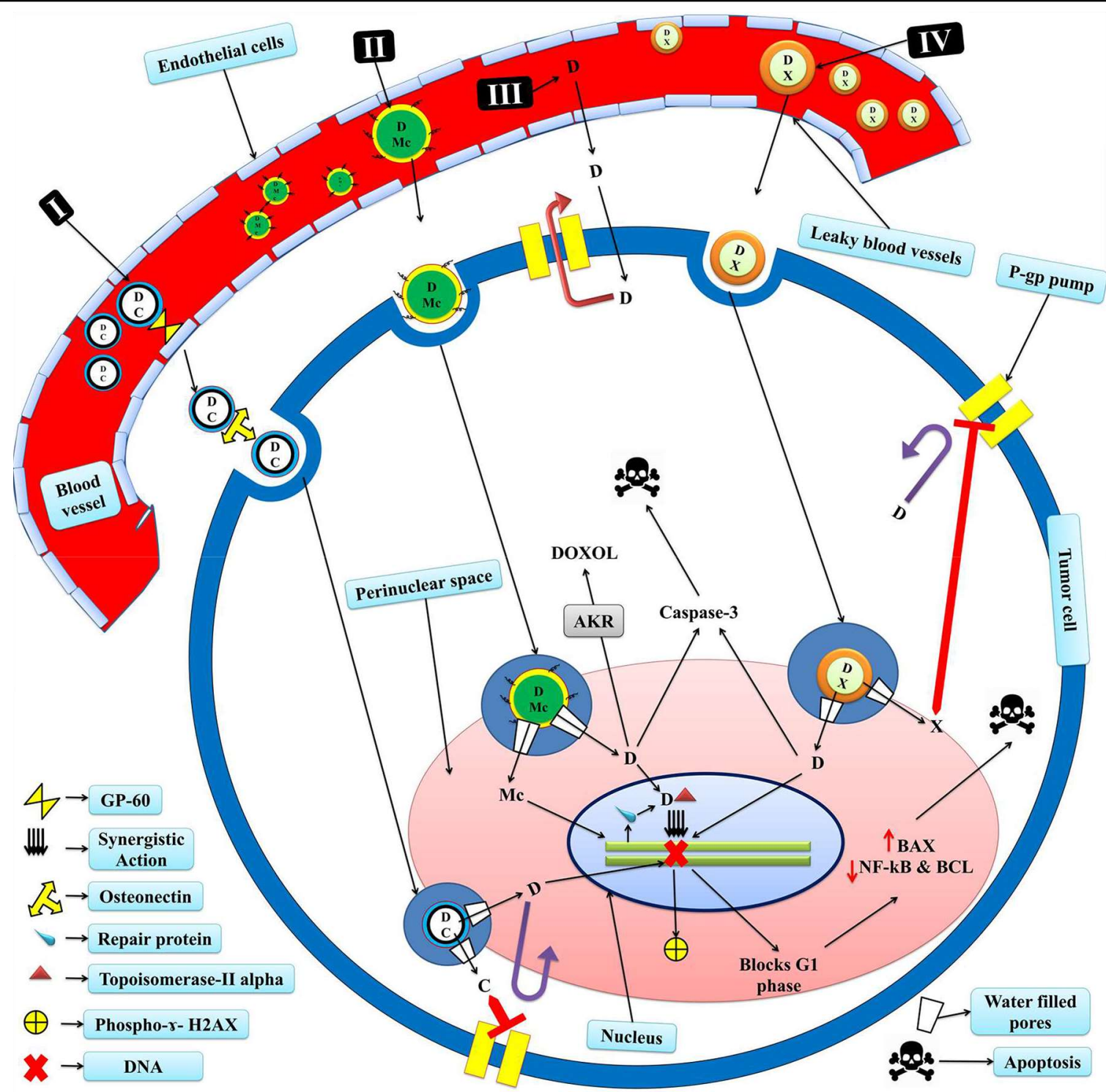

Figure 4: Mechanism I: DC-ANPs use GP-60 to cross endothelial cells \& osteonectin to enter the tumor cell, drug cargo packed inside a vesicle reaches perinuclear space and releases drugs by diffusion through water filled pores. C inhibits P-gp pump and makes D available to induce breaks in DNA. Mechanism II: DM-PLNPs pass to interstitial space from leaky vessels, enters the cell by endocytosis, reaches perinuclear space, drug cargo is released near to nuclear envelope. Mc induces monoalkylation of DNA which forces DNA to synthesize repair proteins. These repair proteins interacts with topoisomerase-II alpha-D-complex. This complex induces breaks in DNA indicated by formation of phosphor-d-H2AX. This D-Mc combination produces synergistic cytotoxic action. Later on D also increases caspase-3 level and thus induces apoptosis. D is metabolized by AKR in to DOXOL. Mechanism III: Free uncapsulated D passes through the endothelial layer of blood vessels, enters the cell by diffusion, readily pumped out by Pgp transporter. Thus emphasizing the importance of encapsulation of D. Mechanism IV: Nanoparticles encapsulating D and X reaches perinuclear space. X blocks the P-gp pump and inhibits the efflux of D. Thus making D available to induce breaks in DNA indicated by increase in BAX and decrease in NF-kB and BCL proteins indicators of apoptosis. Whereas $\mathrm{D}=\mathrm{DOX} ; \mathrm{C}=\mathrm{CUR} ; \mathrm{Mc}=$ MMC; $\mathrm{X}=\mathrm{P}$-gp inhibitor (CUR, MET, RES, ELA); AKR= Aldo Keto Reductase. 
A renowned polymer, PLGA used for co-delivery of DOX and a chemosensitizer RES. The endocytotic mediated entry of DRPCNPs in tumor cells successfully bypasses the efflux mechanism. In the perinuclear region, they release drug cargo by diffusion, $v i a$, water filled pores. RES inhibits the efflux pumps by increasing DOX intracellular accumulation. Subsequently, DOX arrests tumor cells in the G1 phase of the cell-cycle indicated by decreased expression of NF-kB and BCL-2 and increased expression of BAX. Thus, induces apoptosis designated by increased expression of caspase-3 (Zhao et al., 2016). In another way, Shafiei-irannejad et al. (2018), first enhanced the biocompatibility of PLGA by its surface modification with TPGS. Subsequently, modified polymer is co-encapsulated with synergistic drug combination, DOX, and Met. Most of the NPs are taken into the cell by clathrin and caveolae-mediated endocytosis (Schrade et al., 2012), and protected from membrane efflux pumps. In an added advantage to endocytosis, MET and TPGS inhibit the P-gp pump synergistically. Accumulation of Rho-123 points towards the inhibition of P-gp pumps. Thus, increases the nuclear trafficking of DOX. Enhanced accumulation of DOX in the nucleus induces DNA breaks and finally causes cytotoxicity (Figure 4: Mechanism IV). Similarly, Tao et al. (2018) reported the use of core-shell corona-shaped NPs encapsulated with another synergistic combination, DOX, and DSF.

\section{Conclusion}

This systematic review summarizes the enhanced chemotherapeutic effect of DOX in both in vitro and in vivo MDR cancer models. This improved efficacy of DOX was due to the simultaneous codelivery of DOX and CZ/SD by using a suitable drug delivery platform. These nanoformulations not only achieved significant anticancer effects but also masked the life-threatening toxicities of free DOX. By considering all these studies, it is abridged that the small size of NPs helps them to reach tumor cells. The endocytosis mode of delivery of NPs resulted in the delivery of DOX directly near to perinuclear space. Chemosensitizers released blocks efflux pump, whereas synergistic drugs released helped to improve the cytotoxic action of DOX. Focal chemotherapeutic agent DOX diffuses along the nuclear membrane, reaches DNA, and induces cytotoxicity by making double-stranded breaks indicated by increased levels of phospho-dH2AX. This review also summarized the characterization profile, method of preparation, mechanism of action of different CZ/SD loaded along with DOX in NPs. In a word, this review emphasizes to move onward to conduct a meta-analysis of similar reported studies.

\section{Conflict of interest}

The authors declare that there are no conflicts of interest relevant to this article.

\section{References}

Belpomme, D.; Gauthier, S.; Pujade-Lauraine, E.; Facchini, T.; Goudier, M.J.; Krakowski, I.; Netter-Pinon, G.; Frenay, M.; Gousset, C.; Marie, F.N. and Benmiloud, M. (2000). Verapamil increases the survival of patients with anthracycline-resistant metastatic breast carcinoma. Ann. Oncol., 11(11):1471-1476.
Chatterjee, K.; Zhang, J.; Honbo, N. and Karliner, J.S. (2010). Doxorubicin cardiomyopathy. Cardiology, 115(2):155-162. https://doi.org/ $10.1159 / 000265166$

Coley, H.M. (2010). Overcoming Multidrug Resistance in Cancer: Clinical Studies of P-Glycoprotein Inhibitors. In Multidrug Resistance in Cancer, pp:341-358. Humana Press. https://doi.org/10.1007/9781-60761-416-6_15

Ding, S.; Xiong, J.; Lei, D.; Zhu, X.L. and Zhang, H.J. (2018). Recombinant nanocomposites by the clinical drugs of Abraxane ${ }^{\circledR}$ and Herceptin ${ }^{\circledR}$ as sequentially dual-targeting therapeutics for breast cancer. J. Cancer, 9(3):502-511. https://doi.org/10.7150/jca.22163

Duan, J.; Mansour, H.M.; Zhang, Y.; Deng, X.; Chen, Y.; Wang, J.; Pan, Y. and Zhao, J. (2012). Reversion of multidrug resistance by co-encapsulation of doxorubicin and curcumin in chitosan/poly (butyl cyanoacrylate) nanoparticles. Int. J. Pharmaceut., 426(1-2):193-201. https:// doi.org/10.1016/j.ijpharm.2012.01.020

Ducreux, M.; Malka, D.; Mendiboure, J.; Etienne, P.L.; Texereau, P.; Auby, D.; Rougier, P.; Gasmi, M.; Castaing, M.; Abbas, M. and Michel, P. (2011). Sequential versus combination chemotherapy for the treatment of advanced colorectal cancer (FFCD 2000-05): An open-label, randomised, phase 3 trial. Lancet Oncol., 12(11):1032-1044. https://doi.org/https://doi.org/10.1016/S1470-2045(11)70199-1

Elzoghby, A.O.; Samy, W.M. and Elgindy. N.A. (2012). Albumin-based nanoparticles as potential controlled release drug delivery systems. J. Control Release, 157(2):168-182. https://doi.org/https://doi.org/ $10.1016 / \mathrm{j} . \mathrm{jconrel} .2011 .07 .031$

Gao, F.; Zhang, J.; Fu, C.; Xie, X.; Peng, F.; You, J.; Tang. H.; Wang, Z.; Li, P. and Chen, J. (2017). iRGD-modified lipid-polymer hybrid nanoparticles loaded with isoliquiritigenin to enhance anti-breast cancer effect and tumor-targeting ability. Int. J. Nanomed., 12:4147-4162. https://doi.org/10.2147/IJN.S134148

Gaonkar, R.H.; Ganguly, S.; Dewanjee, S.; Sinha, S.; Gupta, A.; Ganguly, S.; Chattopadhyay, D. and Chatterjee, D.M. (2017). Garcinol loaded Vitamin E TPGS emulsified PLGA nanoparticles: Preparation, physicochemical characterization, in vitro and in vivo studies. Sci. Rep., 7(1):1-14. https://doi.org/10.1038/s41598-017-00696-6

Hadinoto, K.; and Sundaresan, A. and Cheow, W.S. (2013). Lipid-polymer hybrid nanoparticles as a new generation therapeutic delivery platform: A review. Eur. J. Pharm. Biopharm., 85(3):427-443. https://doi.org/10.1016/j.ejpb.2013.07.002

Kathawala, R.J.; Gupta, P.; Ashby, Jr.C.R. and Chen, Z.S. (2015). The modulation of $\mathrm{ABC}$ transporter-mediated multidrug resistance in cancer: A review of the past decade. Drug Resist. Update, 18:1-17. https://doi.org/https://doi.org/10.1016/j.drup.2014.11.002

Koffie, R.M.; Farrar, C.T.; Saidi, L.J.; William, C.M.; Hyman, B.T. and SpiresJones, T.L. (2011). Nanoparticles enhance brain delivery of bloodbrain barrier-impermeable probes for in vivo optical and magnetic resonance imaging. P. Natl. Acad. Sci. USA, 108(46):18837-18842. https://doi.org/10.1073/pnas.1111405108

Lee, J.H. and Nan, A. (2012). Combination drug delivery approaches in metastatic breast cancer. J. Drug Deliv., pp:1-17. https://doi.org/ $10.1155 / 2012 / 915375$

Lee, K.A.; Qian, D.Z.; Rey, S.; Wei, H.; Liu, J.O. and Semenza, G.L. (2009). Anthracycline chemotherapy inhibits HIF-1 transcriptional activity and tumor-induced mobilization of circulating angiogenic cells. P. Natl. Acad. Sci. USA, 106(7):2353-2358. https://doi.org/10.1073/ pnas.0812801106

Lin T, Zhao P, Jiang Y, Tang Y, Jin H, Pan Z, He H, Yang, V.C. and Huang, Y. (2016). Blood-brain-barrier-penetrating albumin nanoparticles for biomimetic drug delivery, via, albumin-binding protein pathways for antiglioma therapy. ACS Nano, 10(11):9999-10012. https:// doi.org/https://doi.org/10.1021/acsnano.6b04268 
Lugo MR, S.F. (2005). Interaction of LDS-751 and rhodamine 123 with Pglycoprotein: Evidence for simultaneous binding of both drugs. Biochemistry, 44(42):14020-14029. https://doi.org/https://doi.org/ $10.1021 /$ bi0511179

Mohamed, I. and Skeel, R.T. (2007). Carcinoma of breast. In Roland T. Skeel (Ed.), Handbook of Cancer Chemotherapy, pp:298-322 (7th ed.). Philadelphia: Lippincott Williams and Wilkins, 2007.

Motevalli, S.M.; Eltahan, A.S.; Liu, L.; Magrini, A.; Rosato, N.; Guo, W.; Bottini, M. and Liang, X.-J. (2019). Co-encapsulation of curcumin and doxorubicin in albumin nanoparticles blocks the adaptive treatment tolerance of cancer cells. Biophysics Reports, 5(1):1930. https://doi.org/10.1007/s41048-018-0079-6

Muller, R.H.; Radtke, M. and Wissing, S.A. (2002). Nanostructured lipid matrices for improved microencapsulation of drugs. Int. J. Pharmaceut., 242(1-2):121-128. https://doi.org/https://doi.org/ 10.1016/S0378-5173(02)00180-1

Mussi, S.V.; Sawant, R.; Perche, F.; Oliveira, M.C.; Azevedo, R.B.; Ferreira, L.A.M. and Vladimir, P. (2014). Novel Nanostructured lipid carrier co-loaded with doxorubicin and docosahexaenoic acid demonstrates enhanced in vitro activity and overcomes drug resistance in MCF7/Adr cells. Pharm. Res., 31(8):1882-1892. https://doi.org/ 10.1007/s 11095-013-1290-2

Noorani, L.; Stenzel, M.; Liang, R.; Pourgholami, M.H. and Morris, D.L. (2015). Albumin nanoparticles increase the anticancer efficacy of albendazole in ovarian cancer xenograft model. J. Nanobiotechnol., 13(1):1-12. https://doi.org/10.1186/s12951-015-0082-8

Perche, F. and Torchilin, V.P. (2012). Cancer cell spheroids as a model to evaluate chemotherapy protocols. Cancer Biol. Ther., 13(12):12051213. https://doi.org/10.4161/cbt.21353

Pommier, Y.; Leo, E.; Zhang, H. and Marchand, C. (2010). DNA topoisomerases and their poisoning by anticancer and antibacterial drugs Chemistry and Biology, 17(5):421-433. https://doi.org/10.1016/ j.chembiol.2010.04.012

Prasad, P.; Cheng, J. and Shuhendler, A. (2012). efflux pumps in human breas cancer cells a novel nanoparticle formulation overcomes multiple types of membrane efflux pumps in human breast cancer cells. Drug Deliv. Transl. Re., 2(2):95-105. https://doi.org/10.1007/ s13346-011-0051-1

Prasad, P.; Shuhendler, A.; Cai, P.; Rauth, A.M. and Yu, X. (2013). Doxorubicin and mitomycin $\mathrm{C}$ co-loaded polymer-lipid hybrid nanoparticles inhibit growth of sensitive and multidrug resistant human mammary tumor xenografts. Cancer Lett., 334(2):263-273. https://doi.org/ 10.1016/j.canlet. 2012.08 .008

Radtke, M. and Muller, R. (2001). Nanostructured lipid drug carriers. New Drugs, 2:48-52.

Schrade, A.; Mailander, V.; Ritz, S.; Landfester, K. and Ziener, U. (2012). Surface roughness and charge influence the uptake of nanoparticles: Fluorescently labeled pickering type versus surfactant stabilized nanoparticles. Macromol. Biosci., 12(11):1459-1471. https:// doi.org/https://doi.org/10.1002/mabi.201200166

Serpe, L.; Satalano, M.G.; Cavalli, R.; Ugazio, E.; Bosco, O.; Canaparo, R.; Muntonia, E.; Frairiab, R.; Gascoc, M.R. and Eandia, M. (2004). Cytotoxicity of anticancer drugs incorporated in solid lipid nanoparticles on HT-29 colorectal cancer cell line. Eur. J. Pharm. Biopharm., 58(3):673-680. https://doi.org/https://doi.org/10.1016/ j.ejpb.2004.03.026
Shafiei-irannejad, V.; Samadi, N.; Salehi, R.; Yousefi, B.; Rahimi, M. and Akbarzadeh, A. (2018). Reversion of multidrug resistance by coencapsulation of doxorubicin and metformin in poly (lactide-coglycolide) - $d$ - $\alpha$-tocopheryl polyethylene glycol 1000 succinate nanoparticles. Pharm. Res., 35(6):119.

Shuhendler, A.J.; Cheung, R.Y.; Manias, J.; Connor, A.; Rauth, A.M. and Wu, X.Y. (2010). A novel doxorubicin-mitomycin C co-encapsulated nanoparticle formulation exhibits anticancer synergy in multidrug resistant human breast cancer cells. Breast Cancer Res. Treat., 119:255-269. https://doi.org/10.1007/s10549-008-0271-3

Suk, J.S.; Xu, Q.; Kim, N.; Hanes, J. and Ensign, L.M. (2016). PEGylation as a strategy for improving nanoparticle-based drug and gene delivery. Adv. Drug Deliver. Rev., 99(Pt A):28-51. https://doi.org/10.1016/ j.addr.2015.09.012.

Tao, X.; Gou, J.; Zhang, Q.; Tan, X.; Ren, T.; Yao, Q.; Tian, B.; Kou, L.; Zhang, L. and Tang, X. (2018). Synergistic breast tumor cell killing achieved by intracellular co-delivery of doxorubicin and disulfiram, via, core-shell-corona nanoparticles. Biomater. Sci-UK., 6(7):18691881. https://doi.org/10.1039/C8BM00271A

Tredan, O.; Galmarini, C.M.; Patel, K. and Tannock, I.F. (2007). Drug resistance and the solid tumor microenvironment. J. Natl. Cancer I., 99(19):1441-1454. https://doi.org/10.1093/jnci/djm135

Wong, H.L.; Bendayan, R.; Rauth, A.M. and Wu, X.Y. (2004). Development of solid lipid nanoparticles containing ionically complexed chemotherapeutic drugs and chemosensitizers. J. Pharm. Sci., 93(8):1993-2008. https://doi.org/https://doi.org/10.1002/jps.20100

Wong, H.L.; Bendayan, R.; Rauth, A.M. and Wu, X.Y. (2006). Simultaneous delivery of doxorubicin and GG918 (Elacridar) by new polymerlipid hybrid nanoparticles (PLN) for enhanced treatment of multidrug-resistant breast cancer. J. Control Release., 116(3):275284. https://doi.org/10.1016/j.jconrel.2006.09.007

Wu, B.; Yu, P.; Cui, C.; Wu, M.; Zhang, Y.; Liu, L.; Wang, C.X.; Zhuo, R.X. and Huang, S.W. (2015). Folate-containing reduction-sensitive lipidpolymer hybrid nanoparticles for targeted delivery of doxorubicin. Biomater. Sci-UK, 3(4):655-664. https://doi.org/https://doi.org/ 10.1039/C4BM00462K

Wu, L.; Chen, M.; Mao, H.; Ningning, W.; Bo, Z.; Zhao, X.; Qian, J. and Changying, X. (2017). Albumin-based nanoparticles as methylprednisolone carriers for targeted delivery towards the neonatal Fc receptor in glomerular podocytes. Int. J. Mol. Med., 39(4):851-860. https:// doi.org/10.3892/ijmm.2017.2902

Yan, T.; Li, D.; Li, J.; Cheng, F.; Cheng, J.; Huang, Y. and He, J. (2016) Effective co-delivery of doxorubicin and curcumin using a glycyrrhetinic acid-modified chitosan-cystamine-poly ( $\varepsilon$-caprolactone) copolymer micelle for combination cancer chemotherapy. Colloid. Surfaces B., 145:526-538. https://doi.org/https://doi.org/10.1016/ j.colsurfb.2016.05.070

Zhang, R.X.; Cai, P.; Zhang, T.; Chen, K.; Li, J.; Cheng, J.; Pang, K.S.; Adissu, H.A.; Rauth, A.M. and Wu, X.Y. (2016). Polymer-lipid hybrid nanoparticles synchronize pharmacokinetics of coencapsulated doxorubicin-mitomycin $\mathrm{C}$ and enable their spatiotemporal co-delivery and local bioavailability in breast tumor. Nanomedicine-Nanotechnol., 12(5):1279-1290. https://doi.org/ 10.1016/j.nano.2015.12.383

Zhao, Y.; Huan, M.L.; Liu, M.; Cheng, Y.; Sun, Y.; Cui, H.; Liu, D.Z.; Mei, Q.B. and Zhou, S.Y. (2016). Doxorubicin and resveratrol co-delivery nanoparticle to overcome doxorubicin resistance. Sci. Rep., 12:6(1):1-5. https://doi.org/10.1038/srep35267

Citation MD Imad Uddin and B Veeresh (2020). Systematic review on screening the role of chemosensitizer or synergistic drug and doxorubicin as dual drug loaded nanoparticle in overcoming multidrug resistant breast cancer. Ann. Phytomed., 9(2):113-124. http://dx.doi.org/10.21276/ap.2020.9.2.9 